DOI: 10.5586/aa.1765

Publication history

Received: 2018-08-22

Accepted: 2019-01-14

Published: 2019-07-01

Handling editor

Barbara Hawrylak-Nowak,

Faculty of Horticulture and

Landscape Architecture,

University of Life Sciences in

Lublin, Poland

Authors' contributions

MiH designed the experiment;

$\mathrm{MdH}, \mathrm{MAM}$, and JF conducted

the experiment; $\mathrm{KP}$ and MSH

performed laboratory analysis;

all authors were involved in

manuscript writing and editing

Funding

This research was funded by

Sher-e-Bangla Agricultural

University Research System

(SAURES).

\section{Competing interest}

$\mathrm{MH}$ served as guest editor of

the issue; other authors: no

competing interests have been

declared

\section{Copyright notice}

() The Author(s) 2019. This is an

Open Access article distributed

under the terms of the

Creative Commons Attribution

License, which permits

redistribution, commercial and

noncommercial, provided that

the article is properly cited.

\section{Citation}

Hasanuzzaman M, Matin MA

Fardus J, Hasanuzzaman $M$,

Hossain MS, Parvin K. Foliar

application of salicylic acid

improves growth and yield

attributes by upregulating the

antioxidant defense system

in Brassica campestris plants

grown in lead-amended soils.

Acta Agrobot. 2019;72(2):1765.

https://doi.org/10.5586/aa.1765

\section{Digital signatur}

This PDF has been certified using digital signature with a trusted timestamp to assure its origin and integrity. A verification trust dialog appears on the PDF document when it is opened in a compatible PDF when is opered in a compatible PDF further Certe furction and a signing reason in case any alteration made to the final content. If the certificat is missing or invalid it is recommended to verify the article on the journal website.
ORIGINAL RESEARCH PAPER

\section{Foliar application of salicylic acid improves growth and yield attributes by upregulating the antioxidant defense system in Brassica campestris plants grown in lead-amended soils}

\author{
Mirza Hasanuzzaman ${ }^{1 *}$, Md. Abdul Matin'1, Jannatul Fardus' ${ }^{1}$, Md. \\ Hasanuzzaman', Md. Shahadat Hossain², Khursheda Parvin ${ }^{2}$ \\ 1 Department of Agronomy, Faculty of Agriculture, Sher-e-Bangla Agricultural University, Sher-e- \\ Bangla Nagar, Dhaka-1207, Bangladesh \\ ${ }^{2}$ Laboratory of Plant Stress Responses, Faculty of Agriculture, Kagawa University, Miki-cho, Kita- \\ gun, Kagawa 761-0795, Japan \\ * Corresponding author. Email:mhzsauag@yahoo.com
}

\begin{abstract}
Lead $(\mathrm{Pb})$ toxicity causes a severe impact on plant growth and productivity. A protective role of salicylic acid (SA) is well known under different abiotic stress conditions. However, very little is known about the SA-induced $\mathrm{Pb}$ resistance mechanism. In this study, we investigated the effect of SA on mustard plants (Brassica campestris L.) under $\mathrm{Pb}$-stress conditions. Plants were exposed to three levels of $\mathrm{Pb}$ amendment to the soil $(0.25,0.50,1.00 \mathrm{mM})$, with or without SA $(0.25 \mathrm{mM})$. Plant growth, yield attributes, and yield at harvest were reduced depending on the severity of the $\mathrm{Pb}$ stress. Exogenous application of SA improved plant growth and yield. Biochemi$\mathrm{cal}$ data revealed that $\mathrm{Pb}$ toxicity resulted in higher oxidative damage by reducing nonenzymatic antioxidants such as ascorbate and glutathione at the higher dose of $\mathrm{Pb}$ treatment. Antioxidant enzymes (ascorbate peroxidase - APX, monodehydroascorbate reductase - MDHAR, dehydroascorbate reductase - DHAR, glutathione reductase - GR, guaiacol peroxidase - POD, glutathione $S$-transferase - GST, and catalase - CAT) responses varied with the $\mathrm{Pb}$ doses. Both the nonenzymatic and enzymatic components of the antioxidant defense system were upregulated after application of SA, resulting in lower oxidative damage under $\mathrm{Pb}$-stress conditions. Taken together, the results suggest that exogenous application of the SA mitigates $\mathrm{Pb}$-induced oxidative damage and consequently results in better growth and yield in mustard plants.
\end{abstract}

\section{Keywords}

abiotic stress; phytohormones; reactive oxygen species; soil pollution; toxic metals

\section{Introduction}

In recent decades, heavy metal contamination of soils, air, and water has increased and posing threats to agricultural ecosystems and environments globally due to rapid urbanization and industrialization. These metals can be taken up by plants from contaminated soil and by atmospheric deposition reducing plant growth and productivity. Subsequent transfer to human beings through the food chain is a potential serious issue with consequences to human health. Among the toxic metals and metalloids, lead $(\mathrm{Pb})$ is a hazardous element along with chromium $(\mathrm{Cr})$, cadmium $(\mathrm{Cd})$, arsenic (As), which are highly poisonous due to their toxic effects on animal and human health [1]. Lead contamination in the environment can result both from natural sources and 
from anthropogenic activities. The main sources of $\mathrm{Pb}$ contamination in the environment are the weathering of $\mathrm{Pb}$-containing rocks and minerals, industrial and refining operations such as the manufacturing of paints, batteries, gasoline, and petroleum. Other sources are from the use of industrial effluents for irrigation, application of biosolids to land, and the excessive use of pesticides and fertilizers. Both animals and plants are adversely affected by $\mathrm{Pb}$ toxicity. Lead is taken up by plants by roots under appropriate soil conditions, but due to its low mobility and a strong binding capacity on to the organic phases in soil and to plant roots, its uptake is generally limited $[1,2]$. However, when lead becomes mobilized it can impact on seed germination and cause malformation of cellular structure, chlorosis, and stunted plant growth. Furthermore, it blocks $\mathrm{K}^{+}, \mathrm{Mg}^{2+}, \mathrm{Ca}^{2+}, \mathrm{Mn}^{2+}, \mathrm{Zn}^{2+}, \mathrm{Fe}^{3+}$ to entry into the root system impacting on cellular functions and subsequently resulting in phytotoxicity to plants $[3,4]$.

When plants are under $\mathrm{Pb}$ stress, several physiological processes are disrupted by the production of increased amounts of reactive oxygen species (ROS) leading to oxidative stress within the plant cells so inhibiting photosynthetic activity, chlorophyll (chl) biosynthesis, hormonal balance, ion homeostasis, membrane stability, ATP production, lipid peroxidation, DNA damage, and imbalances in nutrient and water relations resulting in cell abnormalities and death [5-7]. Plants deal with $\mathrm{Pb}$ toxicity by different physiological and biochemical processes. Amongst the latter, plants endogenously activate both enzymatic and nonenzymatic antioxidant defense systems to scavenge ROS. Nonenzymatic antioxidants such as ascorbate (AsA), reduced glutathione (GSH), oxidized glutathione (GSSG), a-tocopherol, phenolic compounds, alkaloids, and nonprotein amino acids. Enzymatic antioxidants involved either directly or indirectly in scavenging ROS under Pd-stressed conditions include superoxide dismutase (SOD), catalase (CAT), ascorbate peroxidase (APX), monodehydroascorbate reductase (MDHAR), dehydroascorbate reductase (DHAR), glutathione reductase (GR), glutathione peroxidase (GPX), glutathione $S$-transferase (GST), and guaiacol peroxidase (POD) [8-10]. Moreover, some plants can also accumulate different compatible solutes or osmolytes to maintain osmotic adjustment under heavy metal stress conditions. Exogenous application of different phytohormones, including salicylic acid (SA), jasmonic acid, abscisic acid, and gibberellins leads to an induction of signaling cascades which can increase plants growth and productivity under different environmental stresses by enhancing antioxidant activities and scavenging ROS [11,12]. Among these phytohormones, SA acts as an omni-present growth regulator which can regulate various physiological and metabolic processes and it plays an important role in the defense mechanism against lead toxicity [13-15]. It has been reported that SA triggers different gene expressions related to defense, either directly or by the $\mathrm{H}_{2} \mathrm{O}_{2}$-mediated signal transduction pathway which regulates mitogen-activated protein kinase (MAPK) [16]. Previous research has elucidated that foliar supplementation of SA increases resistance under different heavy metal stress conditions in different crops, such as $\mathrm{Pb}$ stress in rice and barley $[17,18]$ and Cd stress in maize [19]. Exogenous application of SA can maintain the stability and integrity of the cell membrane [19], increase the antioxidant activity by reducing ROS [20,21], upregulate heme oxygenase [22], improve the photosynthetic capacity [23], and reduce heavy metal uptake [24,25]. Brassica species are notable accumulators of heavy metals and possess a strong antioxidant defense mechanism to deal with heavy metal toxicity. However, the effect of SA on the B. campestris under lead-stressed conditions has yet to be studied. The present study was carried out to understand the antioxidant mechanisms of $\mathrm{Pb}$-induced heavy metal stress in B. campestris after foliar application of SA.

\section{Material and methods}

\section{Plant materials and treatments applied}

Seed of B. campestris 'SAU Sarisha-3' was obtained from Sher-e-Bangla Agricultural University, Dhaka, Bangladesh. Before sowing, the soil was mixed with the recommended dose of fertilizer and 2-L uniform-sized pots were filled with the mixed soil. After germination, the mustard seedlings were thinned to three uniform and healthy 
plants in each pot. Four $\mathrm{Pb}$ treatments including a control (no treatment) were applied on days $28,35,42,49$, and 56 after sowing. The treatments were $\mathrm{C}$ (control), $\mathrm{Pb}_{0.25}(0.25$ $\mathrm{mM} \mathrm{Pb}), \mathrm{Pb}_{0.5}(0.5 \mathrm{mM} \mathrm{Pb})$, and $\mathrm{Pb}_{1.0}(1.0 \mathrm{mM} \mathrm{Pb}) . \mathrm{Pb}\left(\mathrm{NO}_{3}\right)_{2}$ was used as the source of $\mathrm{Pb}$. Salicylic acid (SA) at $0.25 \mathrm{mM}$ concentration was used as a protectant applied as spray solution (at 3-day interval) under the $\mathrm{Pb}$-stressed conditions $\left(\mathrm{Pb}_{0.25+\mathrm{SA}}, \mathrm{Pb}_{0.5+\mathrm{SA}}\right.$, $\left.\mathrm{Pb}_{1.0+\mathrm{SA}}\right)$. A randomized complete block design (RCBD) was used to set up the experiment with three replications. The experiment was carried out in a polythene shed house and allowed to grow until harvest and samplings were done at different stages based on the requirements. Two sets of plants were grown - one for growth and biochemical analyses and the other for yield attributes and measurement.

\section{Measurement of relative water content}

Relative water content (RWC) was measured using the method of Barrs and Weatherley [26]. Fresh weight (FW) of three leaf blades was taken from the randomly selected plant. Then, turgid weight (TW) was taken after soaking the leaf blades in a Petri dish with distilled water for $4 \mathrm{~h}$ in dark conditions. Finally, the leaf blades were placed in a drying oven at $80^{\circ} \mathrm{C}$ for $48 \mathrm{~h}$ and dry weight (DW) was recorded. RWC was then calculated using the following formula: $R W C \%=F W-D W / T W-D W \times 100$.

\section{Measurement of chlorophyll content (as SPAD)}

Leaf chl content was measured as a soil plant analysis development (SPAD) index - an indirect method of chlorophyll measurement with the Minolta SPAD-502 (Konica Minolta Sensing, Tokyo, Japan). Measurements were taken from the middle of the lamina of the second leaf from the upper for each $\mathrm{Pb}$-treated and control conditions.

\section{Assaying lipid peroxidation}

MDA estimation was used as the main measure of lipid peroxidation and was assessed using a slight modification of the methods of Heath and Packer [27], employing thiobarbituric acid (TBA) as a reactive substance. Leaf samples $(0.5 \mathrm{~g})$ were homogenized in $5 \%$ trichloroacetic acid and centrifuged it at $11,500 \mathrm{~g}$ for $15 \mathrm{~min}$ and then mixed with $4 \mathrm{~mL}$ of the reaction mixture $(0.5 \%$ TBA dissolved in $20 \%$ TCA). The mixture was then boiled for $30 \mathrm{~min}$ at $95^{\circ} \mathrm{C}$ and cooled quickly in an ice bath and then again centrifuged as before. The absorbance of the solution was measured at 532 and 600 $\mathrm{nm}$ using spectrophotometer. The absorbance at $600 \mathrm{~nm}$ was used as the nonspecific and was deducted from reading at $532 \mathrm{~nm}$ to get the actual absorbance. The MDA concentration was then determined and expressed as nmol g ${ }^{-1}$ fresh weight.

\section{Estimation of $\mathrm{H}_{2} \mathrm{O}_{2}$}

The method of $\mathrm{Yu}$ et al. [28] was used to assess $\mathrm{H}_{2} \mathrm{O}_{2}$. Half gram of leaf samples were homogenized in $3 \mathrm{~mL}$ potassium-phosphate buffer $(50 \mathrm{mM})$ at $6.5 \mathrm{pH}$ and centrifuged at $11,500 \mathrm{~g}$ for $15 \mathrm{~min}$. The supernatant was then mixed with $0.1 \% \mathrm{TiCl}_{4}$ dissolved in $1 \mathrm{~mL}$ of $20 \% \mathrm{H}_{2} \mathrm{SO}_{4}$ and then the mixture was left at room temperature for $10 \mathrm{~min}$, and centrifuged again as before. The absorbance was measured at $410 \mathrm{~nm}$, and the concentration of $\mathrm{H}_{2} \mathrm{O}_{2}$ expressed as $\mathrm{mol} \mathrm{g}^{-1}$ fresh weight.

\section{Ascorbate and glutathione extraction and assay}

Three $\mathrm{mL}$ of aliquots of acidic extraction buffer ( 1 mM EDTA in 5\% metaphosphoric acid) were used in a cold condition to homogenize $0.5 \mathrm{~g}$ of fresh leaves with a pestle and mortar and then centrifuged for $15 \mathrm{~min}$ at $11,500 \mathrm{~g}$ and $4^{\circ} \mathrm{C}$. After centrifugation, the ascorbate and glutathione concentrations were analyzed in the supernatant solution. 
After a slight modification of the methods of Huang et al. [29], the ascorbate concentration was measured. 0.5 M K-P buffer was used to neutralize the supernatant solution and then AsA was determined spectrophotometrically at $265 \mathrm{~nm}$ in $100 \mathrm{mM}$ K-P buffer ( $\mathrm{pH}$ 7.0). Ascorbate concentrations were then calculated from a standard calibration curve.

The glutathione pool was determined with slight modification of the method of Paradiso et al. [30], where 0.5 M K-P buffer ( $\mathrm{pH} 7.0$ ) was used to neutralize the supernatant. Then, 5,5'-dithio-bis(2-nitrobenzoic acid) (DTNB) was used to oxidize GSH which was then reduced by NADPH in the presence of GR. After reduction of DTNB, 2-nitro5-thiobenzoic acid (NTB) was generated and its absorption was measured at $412 \mathrm{~nm}$. 2-Vinylpyridine was used to remove GSH for measuring GSSG. The final calculation of GSH and GSSG was from standard curves from known concentrations. GSH concentration was calculated by GSSG subtraction from the total GSH concentration.

\section{Enzyme extraction and measurement}

One $\mathrm{mL}$ of $50 \mathrm{mM} \mathrm{K-P}$ buffer (pH 7.0) containing $100 \mathrm{mM} \mathrm{KCl,} 1 \mathrm{mM}$ ascorbate, 5 $\mathrm{mM} \beta$-mercaptoethanol and $10 \%$ glycerol was used to homogenize $0.5 \mathrm{~g}$ of fresh leaves and then centrifuged for not more than $10 \mathrm{~min}$ at $11,500 \mathrm{~g}$. After centrifugation, the supernatant was collected to determine enzyme activity. The same supernatant was also used to determine protein concentration using the method of Bradford [31].

Ascorbate peroxidase (APX; EC: 1.11.1.11) activity. The activity of APX was measured following Nakano and Asada's [32] procedure. The reaction buffer contained $50 \mathrm{mM}$ K-P buffer ( $\mathrm{pH}$ 7.0), $0.5 \mathrm{mM}$ AsA, $0.1 \mathrm{mM} \mathrm{H}_{2} \mathrm{O}_{2}, 0.1 \mathrm{mM}$ EDTA, and enzyme extract. When reactions started after the addition of $\mathrm{H}_{2} \mathrm{O}_{2}$, the color was changed and the APX activity was assayed spectrometrically at $290 \mathrm{~nm}$ absorbance.

Monodehydroascorbate reductase (MDHAR; EC: 1.6.5.4). The MDHAR activity was determined according to the method of Hossain et al. [33] and measured by preparing a reaction mixture which contained $50 \mathrm{mM}$ Tris- $\mathrm{HCl}$ buffer ( $\mathrm{pH} 7.5), 0.2 \mathrm{mM} \mathrm{NADPH}$, $2.5 \mathrm{mM}$ AsA, and 0.5 unit of ascorbate oxidase (AO; EC 1.10.3.3) and enzyme solution. After the addition of AO, the reaction started and then the MDHAR activity was determined at $340 \mathrm{~nm}$ absorbance.

Dehydroascorbate reductase (DHAR; EC: 1.8.5.1) activity. The DHAR activity was assayed at $265 \mathrm{~nm}$ absorbance following the procedure of Nakano and Asada [32] using a reaction buffer where the enzyme solution was mixed with $50 \mathrm{mM} \mathrm{K}-\mathrm{P}$ buffer ( $\mathrm{pH}$ 7.0), $2.5 \mathrm{mM} \mathrm{GSH}$, and $0.1 \mathrm{mM}$ dehydroascorbate.

Glutathione reductase (GR; EC: 1.6.4.2) activity. The procedure of Hossain et al. [34] was employed. The reaction mixture contained 0.1 M K-P buffer ( $\mathrm{pH} 7.8$ ), 1 mM EDTA, $1 \mathrm{mM}$ GSSG, $0.2 \mathrm{mM}$ NADPH mixed with extracting enzyme. GR was determined with measuring the absorbance at $340 \mathrm{~nm}$ which was initiated with GSSG.

Glutathione S-transferase (GST; EC: 2.5.1.18) activity. After a slight modification of the method of Hossain et al. [35], GST was assayed using a reaction mixture containing $100 \mathrm{mM}$ Tris- $\mathrm{HCl}$ buffer ( $\mathrm{pH}$ 6.5), $1.5 \mathrm{mM} \mathrm{GSH}, 1 \mathrm{mM}$ 1-chloro-2,4-dinitrobenzene (CDNB), and extracted enzyme. The activity of GST was measured at $340 \mathrm{~nm}$ with increasing absorbance which was initiated by CDNB addition.

Guaiacol peroxidase (POD; EC: 1.11.1.7) activity. Phosphate buffer (0.1 M) (pH 7.0), $0.04 \mathrm{~mL}$ of $0.1 \mathrm{M} \mathrm{H}_{2} \mathrm{O}_{2}, 0.04 \mathrm{~mL}$ of $0.2 \% \mathrm{O}$-dianisidine, and $0.02 \mathrm{~mL}$ of enzyme extract was mixed to prepare a reaction mixture and then POD activity was measured at 470 $\mathrm{nm}$ following the method of Shannon et al. [36].

Catalase (CAT; EC: 1.11.1.6) activity. The enzyme solution was mixed with reaction buffer [ $50 \mathrm{mM} \mathrm{K}-\mathrm{P}$ buffer ( $\mathrm{pH}$ 7.0), $15 \mathrm{mM} \mathrm{H}_{2} \mathrm{O}_{2}$ ] to estimate CAT activity and then absorbance was determined at $240 \mathrm{~nm}$ following the method of Hossain et al. [34]. 


\section{Assaying yield and yield-contributing attributes}

Plant heights were measured in each pot, from soil level to leaf apex. Primary and secondary branches of plants were also recorded as the number per plant and as a determinant of plant yield. Similarly, the number of pods per plant and seeds per pod were recorded from randomly selected plants from each pot. One hundred clean, sun-dried grains were weighed after random collection from the seed stock and then converted into the weight per 1,000 seeds. After the complete sun-drying process, the biomass from each pot was threshed manually, and the seed yield per pot was recorded and then converted it into $\mathrm{kg} \mathrm{ha}^{-1}$. The straw was also weighed to determine biological yield. The biological yield was calculated by using the following formula: Biological yield $=$ Grain yield + Straw yield .

Finally, a harvest index (HI) was calculated by using the following formula of Gardner et al. [37]: $H I=$ Grain yield $/$ Biological yield $\times 100$.

\section{Statistical analysis}

The software package XLSTAT 2017 [38] was used to analyze the all data using analysis of variance (ANOVA) for all parameters and the significance of differences between treatment means tested by LSD at the $5 \%$ level of significance.

\section{Results}

\section{Growth and biomass}

Mustard plants exposed to increasing doses of $\mathrm{Pb}$ showed a reduction in plant height, FW, and DW at 30 days after sowing (DAS), 45 DAS, and at harvest. The greatest growth and biomass reductions (37\% in height, $49 \%$ in FW, $24 \%$ in DW, 22\% in primary branch number, and $36 \%$ in secondary branch number) compared to the control were observed at $45 \mathrm{DAS}$ for plants treated with $1 \mathrm{mM} \mathrm{Pb}$ (Tab. 1 and Fig. 1). It was notable that in most cases, application of SA improved plant growth and biomass suffering $\mathrm{Pb}$ toxicity compared to $\mathrm{Pb}$-treated plants alone. Under severe $\mathrm{Pb}$-induced stress, exogenous $\mathrm{SA}$ could not significantly improve growth and biomass (Tab. 1 and Fig. 1).

\section{Relative water content}

RWC decreased with increasing $\mathrm{Pb}$ in a dose-dependent manner. The reduction was by $20 \%, 30 \%$, and $31 \%$ compared to the control at $0.25,0.5$, and $1 \mathrm{mM} \mathrm{Pb}$, respectively (Fig. 2). However, SA application increased the RWC by $12 \%, 17 \%$, and $10 \%$ in 0.25 , 0.5 , and $1 \mathrm{mM} \mathrm{Pb}$-affected mustard plants, respectively, compared to only $\mathrm{Pb}$-treated plants.

\section{Chlorophyll content}

Lead stress decreased the photosynthetic pigment content as indicated by SPAD values. The chlorophyll reduction was detected in a dose-dependent manner, where the greatest reduction (27\%) was observed in the $1 \mathrm{mM} \mathrm{Pb}$ treatment. By contrast, exogenous SA improved chlorophyll contents compared to the $\mathrm{Pb}$-stressed plants but remained lower than that of the control plants (Fig. 2).

\section{Yield components}

Lead stress greatly impacted on the yield contributing components and the overall yield of the mustard plants in a dose-dependent manner. Reductions in these parameters 
Tab. 1 Salicylic acid-induced changes in plant height and biomass of mustard plants exposed to lead toxicity.

\begin{tabular}{|c|c|c|c|c|c|c|c|}
\hline \multirow[b]{2}{*}{ Treatment } & \multicolumn{3}{|c|}{ Plant height $(\mathrm{cm})$} & \multicolumn{2}{|c|}{ Fresh weight (g) } & \multicolumn{2}{|c|}{ Dry weight (g) } \\
\hline & 30 DAS & 45 DAS & At harvest & 30 DAS & 45 DAS & 30 DAS & 45 DAS \\
\hline Control & $15.08 \pm 0.96^{\mathrm{a}}$ & $55.33 \pm 3.78^{\mathrm{a}}$ & $96.25 \pm 6.38^{\text {a }}$ & $2.65 \pm 0.33^{a}$ & $19.75 \pm 1.85^{\mathrm{a}}$ & $0.384 \pm 0.037^{a}$ & $3.39 \pm 0.22^{a}$ \\
\hline $\mathrm{Pb}_{0.25}$ & $17.50 \pm 0.79 \mathrm{bc}$ & $40.67 \pm 3.41^{\mathrm{bc}}$ & $86.00 \pm 6.42^{\mathrm{b}}$ & $2.09 \pm 0.18^{\text {bcd }}$ & $14.00 \pm 1.47 \mathrm{~cd}$ & $0.340 \pm 0.026^{\mathrm{ab}}$ & $2.88 \pm 0.27^{b}$ \\
\hline $\mathrm{Pb}_{0.25+\mathrm{SA}}$ & $15.08 \pm 0.83^{\mathrm{a}}$ & $45.50 \pm 3.18^{b}$ & $89.50 \pm 5.67 \mathrm{ab}$ & $2.37 \pm 0.16^{\mathrm{ab}}$ & $16.00 \pm 1.00^{\mathrm{b}}$ & $0.358 \pm 0.025^{\mathrm{ab}}$ & $3.08 \pm 0.25^{\mathrm{ab}}$ \\
\hline $\mathrm{Pb}_{0.5}$ & $18.83 \pm 1.97^{c}$ & $36.17 \pm 3.28^{\mathrm{cd}}$ & $73.25 \pm 6.30^{c}$ & $2.03 \pm 0.17^{\mathrm{cd}}$ & $11.75 \pm 1.32^{\text {ef }}$ & $0.315 \pm 0.024^{\text {bc }}$ & $2.51 \pm 0.21^{\mathrm{cd}}$ \\
\hline $\mathrm{Pb}_{0.5+\mathrm{SA}}$ & $16.92 \pm 1.29$ ab & $41.92 \pm 2.89^{\mathrm{b}}$ & $75.63 \pm 5.11^{c}$ & $2.19 \pm 0.14^{\mathrm{bc}}$ & $15.08 \pm 1.49^{\mathrm{bc}}$ & $0.318 \pm 0.023^{b c}$ & $2.81 \pm 0.22^{b c}$ \\
\hline $\mathrm{Pb}_{1.0}$ & $19.00 \pm 1.56^{c}$ & $35.00 \pm 3.62^{d}$ & $71.08 \pm 4.47^{c}$ & $1.85 \pm 0.14^{\mathrm{d}}$ & $10.00 \pm 0.71^{\mathrm{f}}$ & $0.291 \pm 0.041^{c}$ & $2.33 \pm 0.18^{\mathrm{d}}$ \\
\hline $\mathrm{Pb}_{1.0+\mathrm{SA}}$ & $17.42 \pm 1.26^{\mathrm{ab}}$ & $35.67 \pm 3.66^{\mathrm{cd}}$ & $70.38 \pm 5.68^{c}$ & $1.96 \pm 0.19^{\mathrm{cd}}$ & $12.25 \pm 1.04^{\mathrm{de}}$ & $0.313 \pm 0.034^{b c}$ & $2.30 \pm 0.29^{\mathrm{d}}$ \\
\hline
\end{tabular}

Here, $\mathrm{Pb}_{0.25}, \mathrm{~Pb}_{0.5}, \mathrm{~Pb}_{1.0}$, and $\mathrm{SA}$ indicates $0.25 \mathrm{mM} \mathrm{Pb}\left(\mathrm{NO}_{3}\right)_{2}, 0.5 \mathrm{mM} \mathrm{Pb}\left(\mathrm{NO}_{3}\right)_{2}, 1.0 \mathrm{mM} \mathrm{Pb}\left(\mathrm{NO}_{3}\right)_{2}$, and $0.5 \mathrm{mM}$ salicylic acid, respectively. Means $\pm S D$ are calculated from four replicates. In the same column, letter(s) indicates no statistical difference according to Tukey's honest significant difference test at $p \leq 0.05$.

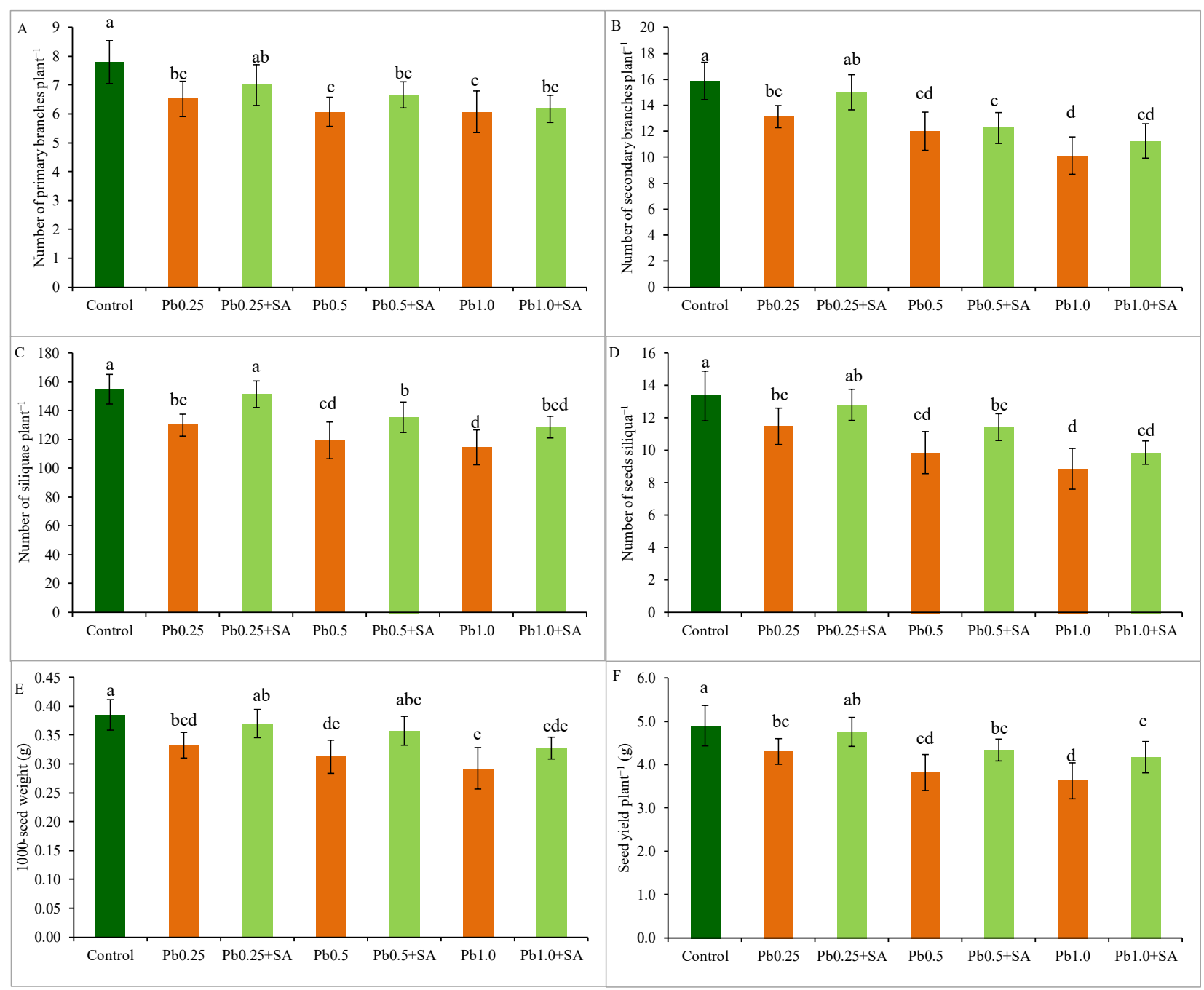

Fig. 1 Salicylic acid-induced changes in yield contributing characters and seed yield of mustard plants exposed to lead toxicity. Here, $\mathrm{Pb}_{0.25}, \mathrm{~Pb}_{0.5}, \mathrm{~Pb}_{1.0}$, and SA indicates $0.25 \mathrm{mM} \mathrm{Pb}\left(\mathrm{NO}_{3}\right)_{2}, 0.5 \mathrm{mM} \mathrm{Pb}\left(\mathrm{NO}_{3}\right)_{2}, 1.0 \mathrm{mM} \mathrm{Pb}\left(\mathrm{NO}_{3}\right)_{2}$, and $0.5 \mathrm{mM}$ salicylic acid, respectively. Means $\pm S D$ are calculated from four replicates. Bars with different letters are significantly different according to Tukey's honest significant difference test at $p \leq 0.05$. 

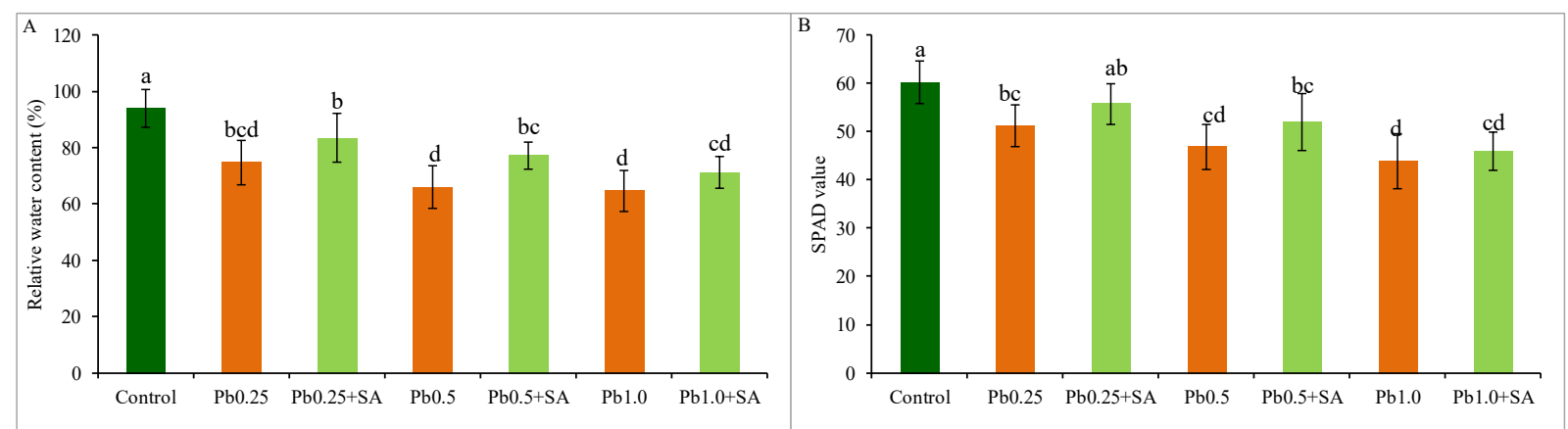

Fig. 2 Salicylic acid-induced changes in leaf relative water content and SPAD value of mustard plants exposed to lead toxicity. Other notes are the same as in Fig. 1.

increased with the increasing $\mathrm{Pb}$ concentrations in the soil. However, maximum yield reductions were found from at the highest dosage of $\mathrm{Pb}(1 \mathrm{mM})$. The $1 \mathrm{mM} \mathrm{Pb}$ treatment caused a reduction of $26 \%$ in the number of siliquae per plant, $34 \%$ in the number of seeds per siliqua, $26 \%$ in 1,000 seed weight, and $26 \%$ in seed yield per plant, compared to controls (Fig. 1). However, foliar spray of SA increased all the above yield attributes under Pb stress. Seed yield was enhanced by $15 \%$ after application of SA under $1 \mathrm{mM}$ $\mathrm{Pb}$ stress compared to the $\mathrm{Pb}$ treatment only (Fig. 1).

\section{Oxidative damage}

Lead stress enhanced oxidative damage as indicated by MDA and $\mathrm{H}_{2} \mathrm{O}_{2}$ contents in a dose-dependent manner. The greatest oxidative stress was detected in the $1 \mathrm{mM} \mathrm{Pb}$ treatment. MDA and $\mathrm{H}_{2} \mathrm{O}_{2}$ increased threefold and twofold, respectively, at $1 \mathrm{mM} \mathrm{Pb}$ compared to controls. Foliar application of SA reduced the MDA and $\mathrm{H}_{2} \mathrm{O}_{2}$ contents significantly in all cases compared to their corresponding Pb-only treatments (Fig. 3).
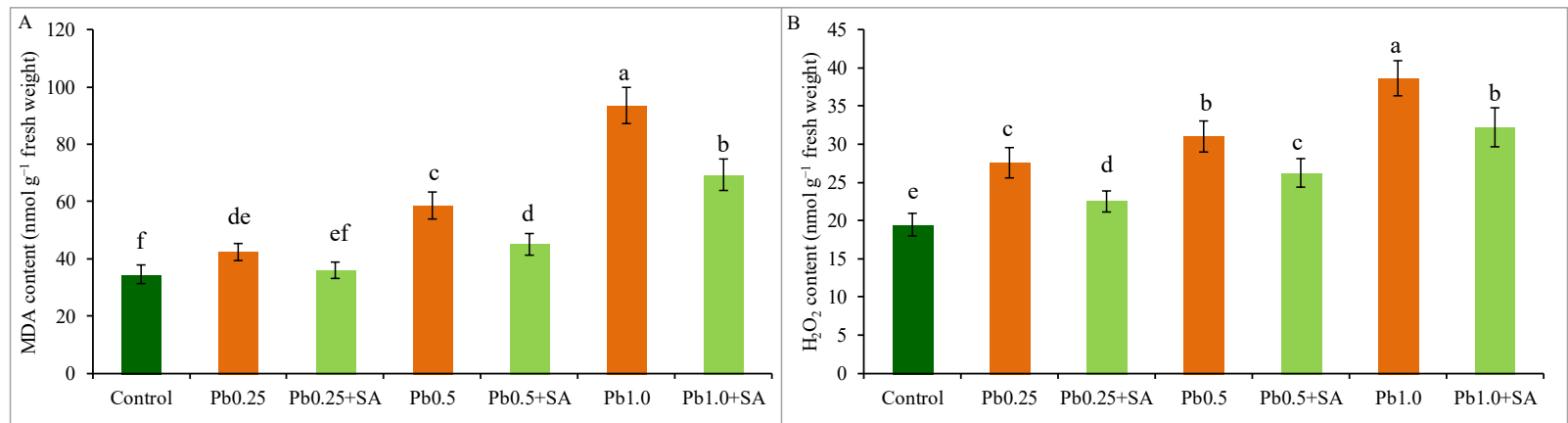

Fig. 3 Salicylic acid-induced changes in oxidative stress markers of mustard plants exposed to lead toxicity. Other notes are the same as in Fig. 1.

\section{Nonenzymatic antioxidants}

The activity of two important antioxidants, AsA and GSH, altered greatly under $\mathrm{Pb}$ stress. Lead stress reduced the AsA content in a dose-dependent manner, whereas the GSH content increased except at the highest dose ( $1 \mathrm{mM}$ ) of $\mathrm{Pb}$ (Fig. 4). The ascorbate content decreased by $14 \%, 28 \%$, and $35 \%$ at $0.25,0.5$, and $1 \mathrm{mM} \mathrm{Pb}$ stress, respectively, compared to the equivalent $\mathrm{Pb}$-only treatments. However, exogenous $\mathrm{SA}$ increased both the AsA and GSH contents under Pb toxicity. The mustard plants had improved GSSG contents upon $\mathrm{Pb}$ exposure dose-dependently along with a decrease of the GSH/GSSG balance in control treatments. Moreover, SA application improved this ratio significantly along with a decrease in GSSG content in all cases under $\mathrm{Pb}$ stress compared to $\mathrm{Pb}$ stress alone (Fig. 4). 


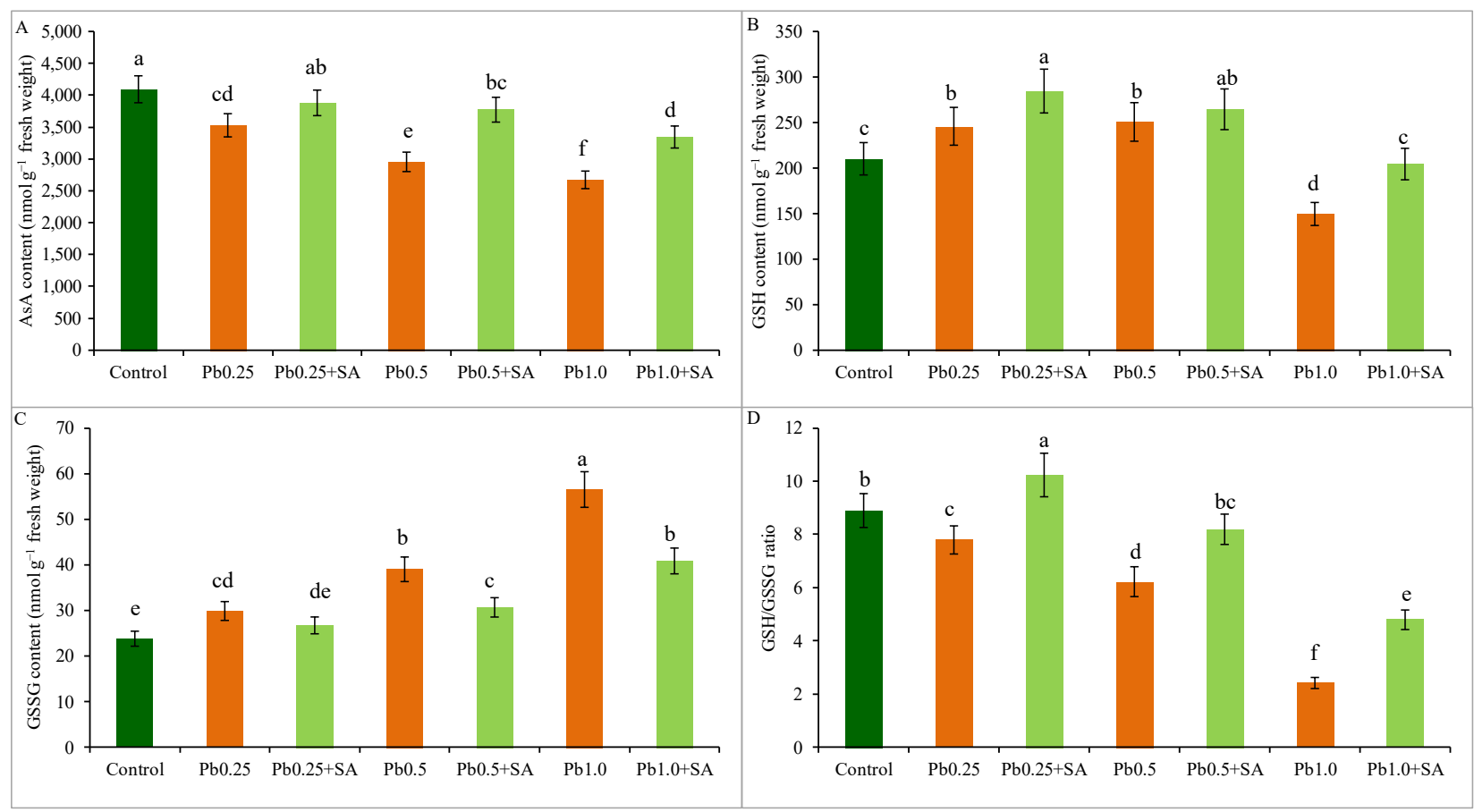

Fig. 4 Salicylic acid-induced changes in ascorbate-glutathione pool of mustard plants exposed to lead toxicity. Other notes are the same as in Fig. 1.

\section{Enzymatic antioxidants}

Enzymes involved in antioxidant defense responded differently to $\mathrm{Pb}$ stress alone and $\mathrm{Pb}$ stress along with SA in the mustard plants. APX and GR activity increased under mild stress $(0.25 \mathrm{mM})$, but the activity of these enzymes decreased with an increase in $\mathrm{Pb}$ doses (Fig. 5). Under mild stress, the APX activity increased by $12 \%$ and the GR activity increased by $24 \%$. With a high dose, APX and GR activity reduced by $27 \%$ and $12 \%$, respectively. CAT, MDHAR, and DHAR activities reduced under Pb stress in a dose-dependent manner (Fig. 5, Fig. 6). GST activity increased at 0.25 and $1.0 \mathrm{mM} \mathrm{Pb}$ stress but did not change at $0.5 \mathrm{mM} \mathrm{Pb}$, whereas POD activity upregulated under mild stress but did not alter at $1.0 \mathrm{mM} \mathrm{Pb}$ compared to the control (Fig. 6). Importantly, exogenous application of SA upregulated all the enzymes, which were downregulated under $\mathrm{Pb}$ stress and further upregulated the enzymes which showed enhanced activity under Pb stress (Fig. 5, Fig. 6).

\section{Discussion}

The present study was conducted to evaluate the effect of exogenous application of SA on $\mathrm{Pb}$-induced stress on mustard plants and observe any improvements in $\mathrm{Pb}$ resistance as apparent in plant growth, physiology, and yield-contributing attributes and to the antioxidant defense system. The results revealed the overall detrimental effect of $\mathrm{Pb}$ with a severe reduction in plant height, branch number, and fresh and dry weights of plants of $B$. campestris compared to the plants grown in the control conditions. This reduction might be due to a higher accumulation of $\mathrm{Pb}$ within plants but this was not measured. Lead treatment induced a reduction in leaf water status, chlorophyll content, and disturbed the cell membrane permeability. Lead toxicity inhibits photosynthesis, resulting in reduced plant height and growth and lower dry matter accumulation and yield. Moreover, $\mathrm{Pb}$ toxicity reduced the activities of enzymes involved in photosynthesis and protein metabolism. Lead-induced reductions in plant growth, chlorophyll biosynthesis, and yield have also been found by others in different crop plants such as Oryza sativa [39], Talinum fruticosum [40], B. juncea [41], and Zea mays [42]. In our study, yield-contributing characters such as the number of siliquae, seeds per siliqua, 

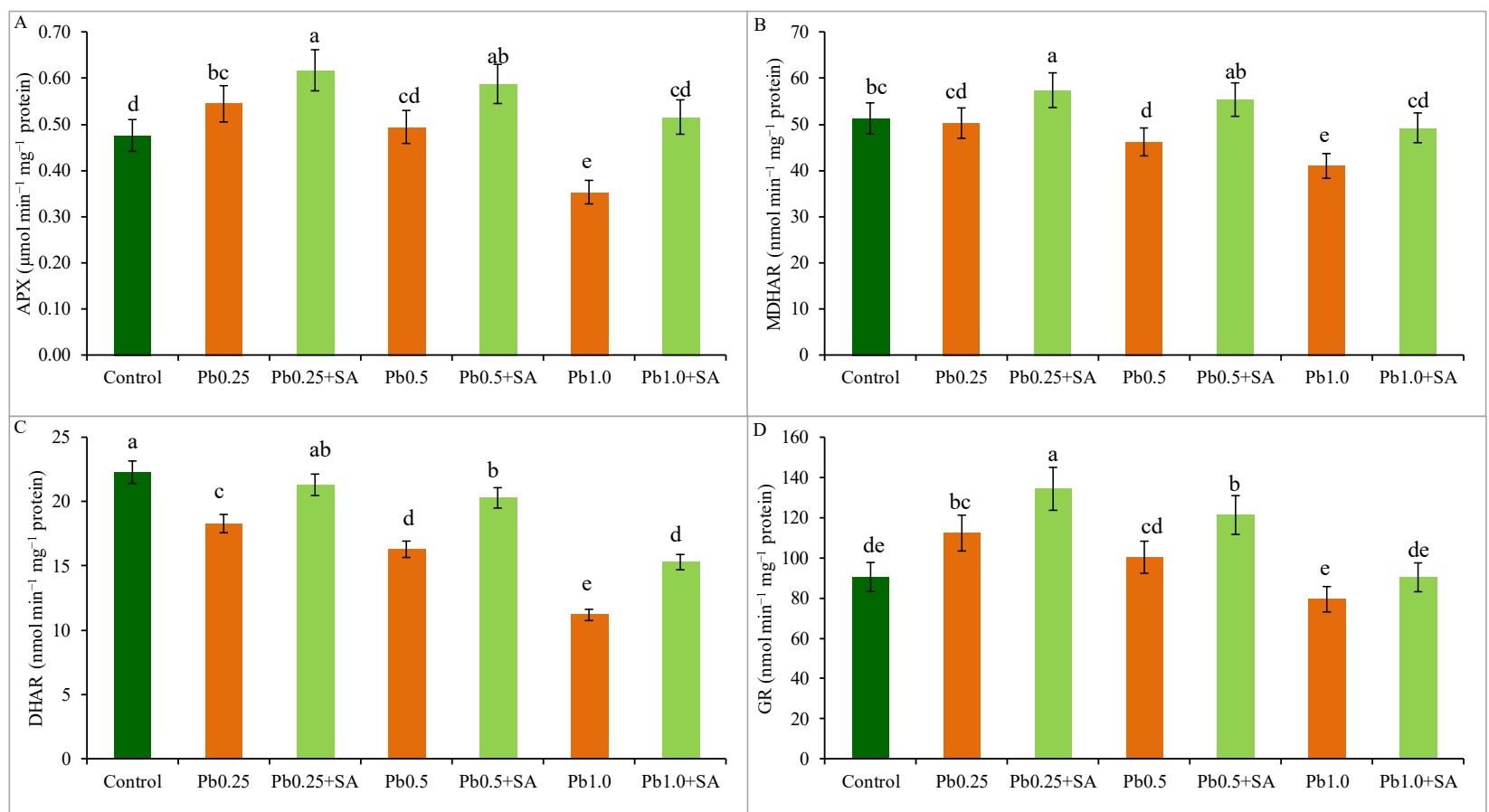

Fig. 5 Salicylic acid-induced changes in AsA-GSH cycle enzymes of mustard plants exposed to lead toxicity. Other notes are the same as in Fig. 1.
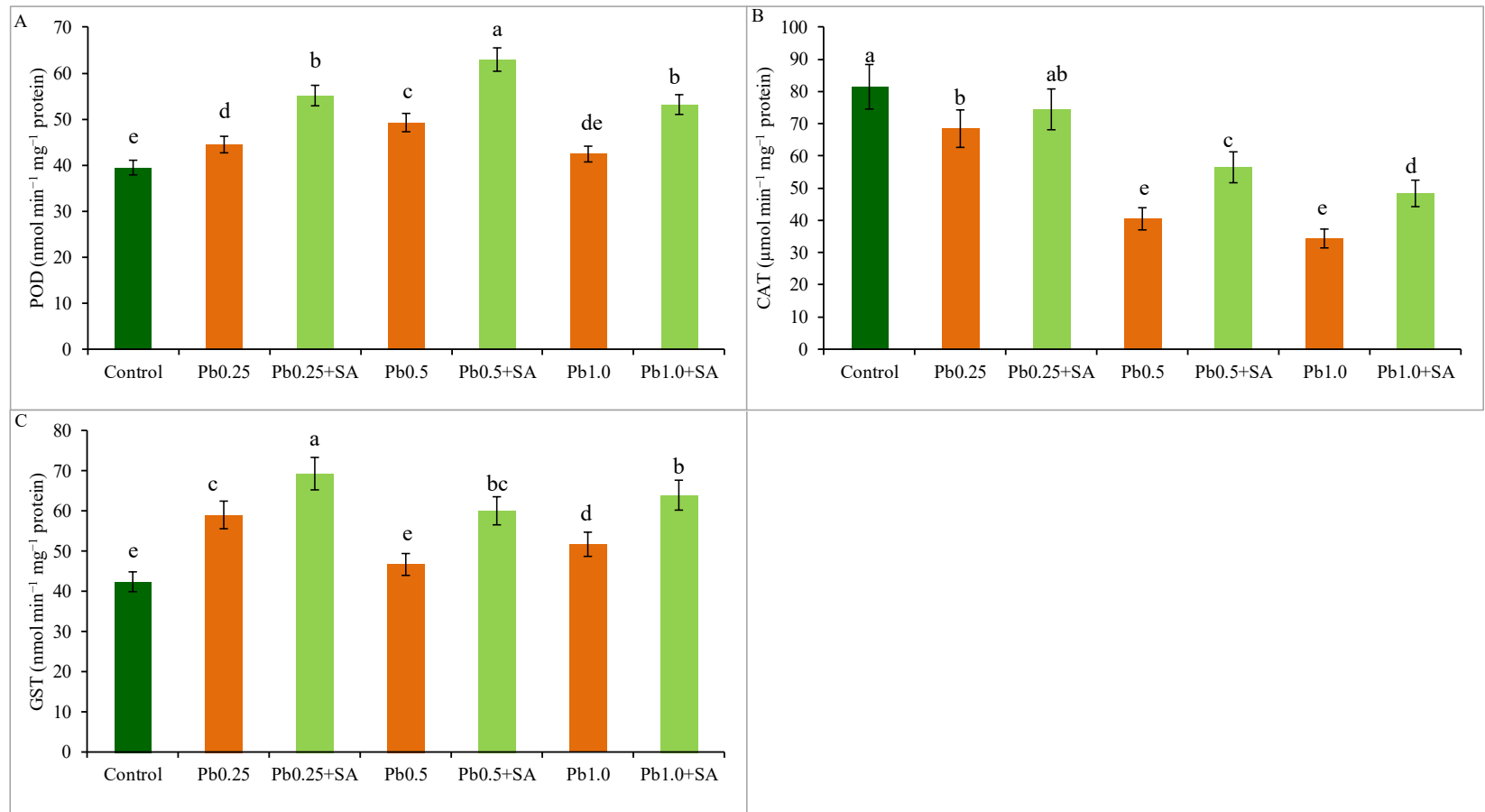

Fig. 6 Salicylic acid-induced changes in the activities of POD (A), CAT (B), and GST (C) of mustard plants exposed to lead toxicity. Other notes are the same as in Fig. 1.

and the 1,000 seed weight all declined under $\mathrm{Pb}$ stress conditions and the impact gradually increased with increasing stress levels. Moreover, our plants grown in $\mathrm{Pb}$ contaminated soil showed a reduction in yield potential and severe yield loss in $1 \mathrm{mM}$ $\mathrm{Pb}$-treated plants. This reduction of yield could be due to the cumulative effects of a decrease in all yield contributing parameters in plants under $\mathrm{Pb}$-stressed conditions. Previously, Ashraf and Tang [39] reported that a deterioration of yield-contributing characters is responsible for yield reduction under heavy metal stress conditions in their experiments. 
Supplementation with SA to $\mathrm{Pb}$-induced plants increased growth, biomass, and yield, which might be due to increasing water content and chlorophyll biosynthesis. SA significantly improved water content and biosynthesis of photosynthetic pigments, which have been shown to enhance plant growth, biomass accumulation, and net photosynthetic rate in mung bean [43]. The present overall results showed a very close relationship between growth parameters and yield with SA application along with an increased plant resistance to $\mathrm{Pb}$ toxicity.

Under heavy metal stressed conditions, plants take up greater amounts of metal ions through the root resulting in toxicity and a severe reduction in growth and productivity [44]. Lead toxicity initiates oxidative stress and induces cellular damage in plants. In this study, $\mathrm{Pb}$-stressed mustard plants showed a greater accumulation of ROS $\left(\mathrm{H}_{2} \mathrm{O}_{2}\right)$ content and thus suffered from oxidative damage. Consequently, increased $\mathrm{H}_{2} \mathrm{O}_{2}$ generation caused greater lipid peroxidation indicated by higher MDA contents. Lead-induced oxidative stress changes in morphology and structural properties of roots in different crops, resulting in a reduction of resistance, has also been demonstrated in other crop plants, e.g., Vigna unguiculata [45], O. sativa [39], B. napus [46], Zea mays [47], Vicia faba [48], Zygophyllum fabago [49], Triticum aestivum [50], and Medicago sativa [51]. Although some plants have developed an efficient antioxidant defense system to resist $\mathrm{Pb}$-induced oxidative stress [51,52], excessive ROS generation results in disruption of the antioxidant defense mechanism, which is the major consequence of $\mathrm{Pb}$ toxicity [45].

Plants require a redox balance for resistance to heavy metal toxicity. Ascorbate and GSH are two major nonenzymatic components of the redox pool, where AsA prevents toxic $\mathrm{H}_{2} \mathrm{O}_{2}$ accumulation by converting $\mathrm{H}_{2} \mathrm{O}_{2}$ to $\mathrm{H}_{2} \mathrm{O}$ assisted by the enzyme APX [53]. Ascorbate peroxidase is the first enzyme which detoxifies $\mathrm{H}_{2} \mathrm{O}_{2}$ to $\mathrm{H}_{2} \mathrm{O}$ with peroxidation of AsA to produce MDHA and DHA by nonenzymatic disproportion, where both MDHAR and DHAR are involved in the regeneration of AsA. Another nonenzymatic antioxidant, GSH which improves defense against abiotic stress, acts a substrate for GPX, restricting protein oxidation and thus reducing ROS generation [54]. In this process, GSH is converted to GSSG by the action of DHAR, which is further rejuvenated by a NADPH-dependent enzyme, GR [55]. Thus, AsA and GSH are directly involved in ROS metabolism, regulated by four vital enzymes, viz. APX, MDHAR, DHAR, and GR. The AsA-GSH cycle therefore acts as a contributor to AsA and GSH production as well as ROS detoxification.

Salicylic acid is an hydroxyl radical scavenger in plants under various abiotic and biotic stresses [56,57]. In this study, it was observed that exogenous application of SA reduced $\mathrm{H}_{2} \mathrm{O}_{2}$ accumulation and MDA contents in plants suffering from the effects of $\mathrm{Pb}$ toxicity. Our observations are consistent with previous studies which have revealed that SA can restrict the entry of heavy metals or metalloids into plants such as As in rice [58], Cr in Zea mays, Cd in Glycine max [59], and Cd in Triticum aestivum [60]. SA enhances the antioxidant defense mechanism, which ultimately improves plant growth and resistance to heavy metal stress [57,61]. SA-induced reduction in ROS production might be due to a restriction in $\mathrm{Pb}$ accumulation in plants and so a decreased oxidative stress. Exogenous application of SA may upregulate the antioxidant defense system through a reduction in MDA and $\mathrm{H}_{2} \mathrm{O}_{2}$ concentrations. In this study, the increasing pattern of both nonenzymatic (AsA, GSH) and enzymatic (APX, GR, CAT, POD) antioxidant components with SA treatment was observed in $\mathrm{Pb}$-stressed mustard plants, which limited ROS production as well as reducing oxidative damage. Higher activity of APX was found with the decreases in both MDHAR and DHAR activity under Pbstressed conditions, which ultimately lower the AsA concentrations and thus decrease the $\mathrm{H}_{2} \mathrm{O}_{2}$ conversion in the $\mathrm{Pb}$-stressed mustard plant. A similar result was found in various Cd-affected crop plant species such as B. juncea [53], Vigna radiata [62], and B. napus [63]. An increase in GSH was found under only moderate $\mathrm{Pb}$ stress, keeping in step with GR-dependent GSH increases and upregulation of GR activity. Under severe $\mathrm{Pb}$ stress, GSH was lower compared to the controls (where less activity of GR was found), which may be due to the affinity of GSH conversion to GSSG during metal detoxification, and thus increased GSSG content [44]. This increase in GSSG further contributed in the lower GSH/GSSG balance under Pb stress, which disrupted the redox balance, an observation which is also supported by other reports $[53,62,64]$. 
Exogenous supplementation of SA to Pb-stressed mustard plants enhanced the upregulation of enzymatic antioxidants in the AsA-GSH pool. Our mustard plants showed stimulated activities of APX, MDHAR, DHAR, and GR under Pb stress by the application of SA. The increase of all these enzymes resulted in greater concentrations of both AsA and GSH as well as enhancing the ROS detoxification rate. Consequently, the plants were released from $\mathrm{Pb}$-induced oxidative stress. Thus, AsA and GSH concentrations and their balance were also improved under stress conditions with SA, as well as reduced $\mathrm{ROS}$ generation which ultimately increased $\mathrm{Pb}$ resistance. The results were consistent with previous studies for SA-induced plant resistance against metal stress in other plants species such as Vigna radiata [43], Triticum aestivum [60], and Cucumis melo [15]. Furthermore, the enzymatic antioxidants POD, GST, and CAT are actively involved in antioxidant defense mechanism through scavenging of excess ROS, where the activities of these enzymes are upregulated when plants are challenged by abiotic stress conditions [44]. In the present study, $\mathrm{Pb}$-treated mustard plants showed greater activities of POD but CAT activity was reduced. A similar result has been reported in Vicia faba roots [48]. Lead contamination significantly increased POD activity (compared to control plants) which is responsible for the detoxification of $\mathrm{H}_{2} \mathrm{O}_{2}$ to $\mathrm{H}_{2} \mathrm{O}$ and $\mathrm{O}_{2}$ [65]. In our study, foliar application of SA showed an increasing trend of POD activity above the control as well as in the Pb-treated plants. We can state that our mustard plants showed increased POD activity to decompose $\mathrm{H}_{2} \mathrm{O}_{2}$ to water under $\mathrm{Pb}$-stress, and also that they became more protected when sprayed with SA.

GST is an important group of enzymes, which actively participate in heavy metal detoxification and hence significantly increased in Pb-stressed mustard plants. The results were consistent with previous studies [66,67] stating that the defensive role of GST enzymes changed due to $\mathrm{Pb}$-induced toxicity and increased over the control treatment. SA supplementation again improved GST activity in Pb-treated plants and thus increased plant resistance further. Exogenous SA application increased GSH contents which further stimulated the activity of GST to scavenge $\mathrm{H}_{2} \mathrm{O}_{2}$ along with its xenobiotic activities.

CAT activity may vary depending on the plant species and severity of a stress. It has been documented that CAT activity elevated in leguminous crops, while it was reduced in rice under heavy metal stress conditions $[45,68,69]$. Moreover, CAT activity increased with a minor stress but decreased in severe conditions [50]. In our case, CAT activity reduced with increasing $\mathrm{Pb}$ concentrations but supplementation of $\mathrm{SA}$ enhanced the CAT activity (Fig. 6B). This increased CAT activity by SA caused lower concentrations of $\mathrm{H}_{2} \mathrm{O}_{2}$ under the stressed conditions. SA can therefore scavenge excess ROS during $\mathrm{Pb}$-stress induced oxidative damage by upregulating antioxidant defense systems even at higher doses of $\mathrm{Pb}(1 \mathrm{mM})$, thus making plants more resistant to this form of abiotic stress.

\section{Conclusion}

Our study concluded that $\mathrm{Pb}$ toxicity might have a severe consequence on the growth of mustard plants and subsequent yield by changing internal physiological mechanisms and inhibiting biosynthesis of photosynthesis pigments. However, exogenous application of SA improved the growth, physiology, antioxidant activities, yield attributes, and final yield of mustard plants under $\mathrm{Pb}$-stress conditions. The results suggest that foliar application of SA increase $\mathrm{Pb}$-induced stress resistance in mustard plants by mitigating oxidative damage through upregulation of the antioxidant defense system, so improving growth and productivity. 


\section{References}

1. Malar S, Vikram SS, Favas PJC, Perumal V. Lead heavy metal toxicity induced changes on growth and antioxidative enzymes level in water hyacinths [Eichhornia crassipes (Mart.)]. Bot Stud. 2014;55:54. https://doi.org/10.1186/s40529-014-0054-6

2. Wierzbicka M, Przedpełska E, Ruzik R, Ouerdane L, Połeć-Pawlak K, Jarosz M, et al. Comparison of the toxicity and distribution of cadmium and lead in plant cells. Protoplasma. 2007;231:99-111. https://doi.org/10.1007/s00709-006-0227-6

3. Sharma R, Dubey R. Lead toxicity in plants. Braz J Plant Physiol. 2005;17:35-52. https://doi.org/10.1590/S1677-04202005000100004

4. Lakra N, Tomar PC, Mishra SN. Growth response modulation by putrescine in Indian mustard Brassica juncea L. under multiple stress. Indian J Exp Biol. 2016;54:262-270.

5. Hasanuzzaman M, Fujita M. Heavy metals in the environment: current status, toxic effects on plants and possible phytoremediation. In: Anjum NA, Pereira MA, Ahmad IA, Duarte AC, Umar S, Khan NA, editors. Phytotechnologies: remediation of environmental contaminants. Boca Raton, FL, USA: CRC Press; 2012. p. 7-73. https://doi.org/10.1201/b12954-4

6. Nareshkumar A, Veeranagamallaiah G, Pandurangaiah M, Kiranmai K, Amaranathareddy $\mathrm{V}$, Lokesh $\mathrm{U}$, et al. Pb-stress induced oxidative stress caused alterations in antioxidant efficacy in two groundnut (Arachis hypogaea L.). Agricultural Sciences. 2015;6:1283-1297. https://doi.org/10.4236/as.2015.610123

7. Shahid M, Dumat C, Pourrut B, Abbas G, Shahid N, Pinelli E. Role of metal speciation in lead-induced oxidative stress to Vicia faba roots. Russ J Plant Physiol. 2015;62:448-454. https://doi.org/10.1134/S1021443715040159

8. Hasanuzzaman M, Hossain MA, Fujita M. Exogenous selenium pretreatment protects rapeseed plants from cadmium-induced oxidative stress by upregulating antioxidant defense and methylglyoxal detoxification systems. Biol Trace Elem Res. 2012;149:248261. https://doi.org/10.1007/s12011-012-9419-4

9. Hasanuzzaman M, Hossain MA, Jaime A, da Silva T, Fujita M. Plant responses and resistance to abiotic oxidative stress: antioxidant defense is a key factor. In: Bandi V, Shanker AK, Shanker C, Mandapaka M, editors. Crop stress and its management: perspectives and strategies. Dordrecht: Springer; 2012. p. 261-316. https://doi.org/10.1007/978-94-007-2220-0_8

10. Rahman A, Nahar K, Hasanuzzaman M, Fujita M. Manganese induced cadmium stress resistance in rice plants: coordinated action of antioxidant defense, glyoxalase system and nutrient homeostasis. C R Biol. 2016;339:462-474. https://doi.org/10.1016/j.crvi.2016.08.002

11. Khan MIR, Fatma M, Per TS, Anjum NA, Khan NA. Salicylic acid-induced abiotic stress resistance and underlying mechanisms in plants. Front Plant Sci. 2015;6:462. https://doi.org/10.3389/fpls.2015.00462

12. Asgher M, Khan MIR, Anjum NA, Khan NA. Minimizing toxicity of cadmium in plants - role of plant growth regulators. Protoplasma. 2015;252:399-413. https://doi.org/10.1007/s00709-014-0710-4

13. Khan A, Rahman MM, Tania M, Shoshee NF, Xu AH, Chen HC. Antioxidative potential of Duranta repens (Linn.) fruits against $\mathrm{H}_{2} \mathrm{O}_{2}$ induced cell death in vitro. Afr J Tradit Complement Altern Med. 2013;10:436-441. https://doi.org/10.4314/ajtcam.v10i3.9

14. Miura K, Tada Y. Regulation of water, salinity, and cold stress responses by salicylic acid. Front Plant Sci. 2014;5:4. https://doi.org/10.3389/fpls.2014.00004

15. Zhang Y, Xu S, Yang S, Chen Y. Salicylic acid alleviates cadmium-induced inhibition of growth and photosynthesis through upregulating antioxidant defense system in two melon cultivars (Cucumis melo L.). Protoplasma. 2015;252:911-924. https://doi.org/10.1007/s00709-014-0732-y

16. Chai J, Liu J, Zhou J, Xing D. Mitogen-activated protein kinase 6 regulates NPR1 gene expression and activation during leaf senescence induced by salicylic acid. J Exp Bot. 2014;65:6513-6528. https://doi.org/10.1093/jxb/eru369

17. Chen J, Zhu C, Li LP, Sun ZY, Pan XB. Effects of exogenous salicylic acid on growth and $\mathrm{H}_{2} \mathrm{O}_{2}$-metabolizing enzymes in rice plants under lead stress. Journal of Environmental Sciences. 2007;19:44-49. https://doi.org/10.1016/S1001-0742(07)60007-2

18. Arshad T, Maqbool N, Javed F, Wahid A, Arshad MU. Enhancing the defensive mechanism of lead affected barley (Hordeum vulgare L.) genotypes by exogenously 
applied salicylic acid. J Agric Sci. 2017;9:139-146. https://doi.org/10.5539/jas.v9n2p139

19. Belkadhi A, de Haro A, Obregon S, Charbi W, Djebali W. Positive effects of salicylic acid pretreatment on the composition of flax plastidial membrane lipids under cadmium stress. Environ Sci Pollut Res Int. 2015;22:1457-1467. https://doi.org/10.1007/s11356-014-3475-6

20. Li X, Ma L, Bu N, Li Y, Zhang L. Effects of salicylic acid pretreatment on cadmium and/or UV-B stress in soybean plants. Biol Plant. 2014;58:195-199. https://doi.org/10.1007/s10535-013-0375-4

21. Agami RA, Mohamed GF. Exogenous treatment with indole-3-acetic acid and salicylic acid alleviates cadmium toxicity in wheat plants. Ecotoxicol Environ Saf. 2013;94:164171. https://doi.org/10.1016/j.ecoenv.2013.04.013

22. Cui W, Li L, Gao Z, Wu H, Xie Y, Shen W. Haem oxygenase-1 is involved in salicylic acid-induced alleviation of oxidative stress due to cadmium stress in Medicago sativa. J Exp Bot. 2012;63:5521-5534. https://doi.org/10.1093/jxb/ers201

23. Janda T, Gondor OK, Yordanova R, Szalai G, Pál M. Salicylic acid and photosynthesis: signalling and effects. Acta Physiol Plant. 2014;36:2537-2546. https://doi.org/10.1007/s11738-014-1620-y

24. Dražić G, Mihailović N. Salicylic acid modulates accumulation of Cd in plants of Cd-tolerant and Cd-susceptible soybean genotypes. Arch Biol Sci. 2009;61:431-439. https://doi.org/10.2298/ABS0903431D

25. Shi G, Cai Q, Liu Q, Wu L. Salicylic acid-mediated alleviation of cadmium toxicity in hemp plants in relation to cadmium uptake, photosynthesis, and antioxidant enzymes. Acta Physiol Plant. 2009;31:969-977. https://doi.org/10.1007/s11738-009-0312-5

26. Barrs HD, Weatherly PE. A re-examination of relative turgidity for estimating water deficits in leaves. Aust J Biol Sci. 1962;15:413-428. https://doi.org/10.1071/BI9620413

27. Heath RL, Packer L. Photoperoxidation in isolated chloroplasts. I. Kinetics and stoichiometry of fatty acid peroxidation. Arch Biochem Biophys. 1968;25:189-198. https://doi.org/10.1016/0003-9861(68)90654-1

28. Yu CW, Murphy TM, Lin CH. Hydrogen peroxide-induces chilling resistance in mung beans mediated through ABA independent glutathione accumulation. Funct Plant Biol. 2003;30:955-963. https://doi.org/10.1071/FP03091

29. Huang C, He W, Guo J, Chang X, Su P, Zhang L. Increased sensitivity to salt stress in ascorbate-deficient Arabidopsis mutant. J Exp Bot. 2005;56:3041-3049. https://doi.org/10.1093/jxb/eri301

30. Paradiso A, Berardino R, de Pinto M, di Toppi LS, Storelli FT, de Gara L. Increase in ascorbate-glutathione metabolism as local and precocious systemic responses induced by cadmium in durum wheat plants. Plant Cell Physiol. 2008;49:362-374. https://doi.org/10.1093/pcp/pcn013

31. Bradford MM. A rapid and sensitive method for the quantitation of microgram quantities of protein utilizing the principle of protein dye binding. Anal Biochem. 1976;72:248-254. https://doi.org/10.1016/0003-2697(76)90527-3

32. Nakano Y, Asada K. Hydrogen peroxide is scavenged by ascorbate specific peroxidase in spinach chloroplasts. Plant Cell Physiol. 1981;22:867-880. https://doi.org/10.1093/oxfordjournals.pcp.a076232

33. Hossain MA, Nakano Y, Asada K. Monodehydroascorbate reductase in spinach chloroplasts and its participation in the regeneration of ascorbate for scavenging hydrogen peroxide. Plant Cell Physiol. 1984;25:385-395. https://doi.org/10.1093/oxfordjournals.pcp.a076726

34. Hossain MA, Hasanuzzaman M, Fujita M. Up-regulation of antioxidant and glyoxalase systems by exogenous glycinebetaine and proline in mung bean confer resistance to cadmium stress. Physiol Mol Biol Plants. 2010;16:259-272. https://doi.org/10.1007/s12298-010-0028-4

35. Hossain MZ, Hossain MD, Fujita M. Induction of pumpkin glutathione $S$-transferases by different stresses and its possible mechanisms. Biol Plant. 2006;50:210-218. https://doi.org/10.1007/s10535-006-0009-1

36. Shannon LM, Kay E, Lew JY. Peroxidase isozymes from horseradish roots I. Isolation and physical properties. J Biol Chem. 1966;241:2166-2172.

37. Gardner FP, Pearce RB, Mitchell RL. Physiology of crop plants. Iowa State Univ. USA. Int Rice Res. Notes. 1985;27:11-2. 
38. Addinsoft. XLSTAT v. 2017: data analysis and statistics software for Microsoft Excel [Software]. Paris: Addinsoft; 2017.

39. Ashraf U, Tang X. Yield and quality responses, plant metabolism and metal distribution pattern in aromatic rice under lead (Pb) toxicity. Chemosphere. 2017;176:141-155. https://doi.org/10.1016/j.chemosphere.2017.02.103

40. Kumar A, Prasad MNV, Sytar O. Lead toxicity, defense strategies and associated indicative biomarkers in Talinum triangulare grown hydroponically. Chemosphere. 2012;89:1056-1065. https://doi.org/10.1016/j.chemosphere.2012.05.070

41. Kohli SK, Handa N, Sharma A, Gautam V, Arora S, Bhardwaj R, et al. Combined effect of 24-epibrassinolide and salicylic acid mitigates lead $(\mathrm{Pb})$ toxicity by modulating various metabolites in Brassica juncea L. plants. Protoplasma. 2017;255:11-24. https://doi.org/10.1007/s00709-017-1124-X

42. Hussain A, Abbas N, Arshad F, Akram M, Khan ZI, Ahmad K, et al. Effects of diverse doses of lead $(\mathrm{Pb})$ on different growth attributes of Zea mays L. Agricultural Sciences. 2013;4:262-265. https://doi.org/10.4236/as.2013.45037

43. Ali B. Salicylic acid induced antioxidant system enhances the resistance to aluminium in mung bean (Vigna radiata L. Wilczek) plants. Indian J Plant Physiol. 2017;22:178-189. https://doi.org/10.1007/s40502-017-0292-1

44. Nahar K, Hasanuzzaman M, Alam MM, Rahman A, Suzuki T, Fujita M. Polyamine and nitric oxide crosstalk: antagonistic effects on cadmium toxicity in mung bean plants through upregulating the metal detoxification, antioxidant defense and methylglyoxal detoxification systems. Ecotoxicol Environ Saf. 2016;126:245-255. https://doi.org/10.1016/j.ecoenv.2015.12.026

45. Fontenele NMB, Otoch MDLO, Gomes-Rochette NF, de Menezes Sobreira AC, Barreto AAGC, de Oliveira FDB, et al. Effect of lead on physiological and antioxidant responses in two Vigna unguiculata cultivars differing in $\mathrm{Pb}$-accumulation. Chemosphere. 2017;176:397-404. https://doi.org/10.1016/j.chemosphere.2017.02.072

46. Ali B, Xu X, Gill RA, Yang S, Ali S, Tahir M, et al. Promotive role of 5-aminolevulinic acid on mineral nutrients and antioxidative defense system under lead toxicity in Brassica napus. Ind Crops Prod. 2014;52:617-626. https://doi.org/10.1016/j.indcrop.2013.11.033

47. Singh R, Tripathi RD, Dwivedi S, Kumar A, Trivedi PK, Chakrabarty D. Lead bioaccumulation potential of an aquatic macrophyte Najas indica are related to antioxidant system. Bioresour Technol. 2010;101:3025-3032. https://doi.org/10.1016/j.biortech.2009.12.031

48. Shahid M, Dumat C, Pourrut B, Silvestre J, Laplanche C, Pinelli E. Influence of EDTA and citric acid on lead-induced oxidative stress to Vicia faba roots. J Soils Sediments. 2014;14:835-843. https://doi.org/10.1007/s11368-013-0724-0

49. López-Orenes A, Martínez-Pérez A, Calderón AA, Ferrer MA. Pb-induced responses in Zygophyllum fabago plants are organ-dependent and modulated by salicylic acid. Plant Physiol Biochem. 2014;84:57-66. https://doi.org/10.1016/j.plaphy.2014.09.003

50. Lamhamdi M, Bakrim A, Aarab A, Lafont R, Sayah F. Lead phytotoxicity on wheat (Triticum aestivum L.) seed germination and plants growth. C R Biol. 2011;334:118-126. https://doi.org/10.1016/j.crvi.2010.12.006

51. Hattab S, Hattab S, Flores-Casseres ML, Boussetta H, Doumas P, Hernandez LE, et al. Characterisation of lead-induced stress molecular biomarkers in Medicago sativa plants. Environ Exp Bot. 2016;123:1-12. https://doi.org/10.1016/j.envexpbot.2015.10.005

52. Shahid M, Pourrut B, Dumat C, Nadeem M, Aslam M, Pinelli E. Heavy-metal-induced reactive oxygen species: phytotoxicity and physicochemical changes in plants. In: Whitacre DM, editor. Reviews of environmental contamination and toxicology. Cham: Springer; 2014. p. 1-44. (Reviews of Environmental Contamination and Toxicology; vol 232). https://doi.org/10.1007/978-3-319-06746-9_1

53. Mahmud JA, Hasanuzzaman M, Nahar K, Bhuyan MB, Fujita M. Insights into citric acidinduced cadmium resistance and phytoremediation in Brassica juncea L.: coordinated functions of metal chelation, antioxidant defense and glyoxalase systems. Ecotoxicol Environ Saf. 2018;147:990-1001. https://doi.org/10.1016/j.ecoenv.2017.09.045

54. Mahmud JA, Hasanuzzaman M, Nahar K, Rahman A, Hossain MS, Fujita M. $\gamma$-Aminobutyric acid (GABA) confers chromium stress resistance in Brassica juncea L. by modulating the antioxidant defense and glyoxalase systems. Ecotoxicology. 2017;26:675690. https://doi.org/10.1007/s10646-017-1800-9

55. Pandey P, Singh J, Achary V, Reddy MK. Redox homeostasis via gene 
families of ascorbate-glutathione pathway. Front Environ Sci. 2015;3:25. https://doi.org/10.3389/fenvs.2015.00025

56. Khan MIR, Asgher M, Khan NA. Alleviation of salt-induced photosynthesis and growth inhibition by salicylic acid involves glycine betaine and ethylene in mungbean (Vigna radiata L.). Plant Physiol Biochem. 2014;80:67-74. https://doi.org/10.1016/j.plaphy.2014.03.026

57. Liu Z, Ding Y, Wang F, Ye Y, Zhu C. Role of salicylic acid in resistance to cadmium stress in plants. Plant Cell Rep. 2016;35:719-731. https://doi.org/10.1007/s00299-015-1925-3

58. Singh AP, Dixit G, Kumar A, Mishra S, Singh PK, Dwivedi S, et al. Nitric oxide alleviated arsenic toxicity by modulation of antioxidants and thiol metabolism in rice (Oryza sativa L.). Front Plant Sci. 2016;6:1272. https://doi.org/10.3389/fpls.2015.01272

59. Noriega G, Caggiano E, Lecube ML, Santa Cruz D, Batlle A, Tomaro M, et al. The role of salicylic acid in the prevention of oxidative stress elicited by cadmium in soybean plants. Biometals. 2012;25:1155-1165. https://doi.org/10.1007/s10534-012-9577-z

60. Shakirova FM, Allagulova CR, Maslennikova DR, Klyuchnikova EO, Avalbaev AM, Bezrukova MV. Salicylic acid-induced protection against cadmium toxicity in wheat plants. Environ Exp Bot. 2016;122:19-28. https://doi.org/10.1016/j.envexpbot.2015.08.002

61. Zhang F, Zhang H, Xia Y, Wang G, Xu L, Shen Z. Exogenous application of salicylic acid alleviates cadmium toxicity and reduces hydrogen peroxide accumulation in root apoplasts of Phaseolus aureus and Vicia sativa. Plant Cell. 2011;30:1475-1483. https://doi.org/10.1007/s00299-011-1056-4

62. Nahar K, Rahman M, Hasanuzzaman M, Alam MM, Rahman A, Suzuki T, et al. Physiological and biochemical mechanisms of spermine-induced cadmium stress resistance in mung bean (Vigna radiata L.) plants. Environ Sci Pollut Res Int. 2016;23:21206-21218. https://doi.org/10.1007/s11356-016-7295-8

63. Hasanuzzaman M, Nahar K, Gill SS, Alharby HF, Razafindrabe BH, Fujita M. Hydrogen peroxide pretreatment mitigates cadmium-induced oxidative stress in Brassica napus L.: an intrinsic study on antioxidant defense and glyoxalase systems. Front Plant Sci. 2017;8:115. https://doi.org/10.3389/fpls.2017.00115

64. Hasanuzzaman M, Nahar K, Hossain MS, Mahmud JA, Rahman A, Inafuku $\mathrm{M}$, et al. Coordinated actions of glyoxalase and antioxidant defense systems in conferring abiotic stress resistance in plants. Int J Mol Sci. 2017;18:200. https://doi.org/10.3390/ijms18010200

65. Doncheva S, Moustakas M, Ananieva K, Chavdarova M, Gesheva E, Vassilevska R, et al. Plant response to lead in the presence or absence EDTA in two sunflower genotypes (cultivated $H$. annuus $\mathrm{cv} .1114$ and interspecific line $H$. annuus $\times H$. argophyllus). Environ Sci Pollut Res Int. 2013;20:823-833. https://doi.org/10.1007/s11356-012-1274-5

66. Gill SS, Tuteja N. Reactive oxygen species and antioxidant machinery in abiotic stress resistance in crop plants. Plant Physiol Biochem. 2010;48:909-930. https://doi.org/10.1016/j.plaphy.2010.08.016

67. Hasanuzzaman M, Fujita M. Exogenous sodium nitroprusside alleviates arsenicinduced oxidative stress in wheat (Triticum aestivum L.) plants by enhancing antioxidant defense and glyoxalase system. Ecotoxicology. 2013;22:584-596. https://doi.org/10.1007/s10646-013-1050-4

68. Verma S, Dubey RS. Lead toxicity induces lipid peroxidation and alters the activities of antioxidant enzymes in growing rice plants. Plant Sci. 2003;164:645-655. https://doi.org/10.1016/S0168-9452(03)00022-0

69. Reddy AM, Kumar SG, Jyothsnakumari G, Thimmanaik S, Sudhakar C. Lead induced changes in antioxidant metabolism of horsegram [Macrotyloma uniflorum (Lam.) Verdc.] and bengalgram (Cicer arietinum L.). Chemosphere. 2005;60:97-104. https://doi.org/10.1016/j.chemosphere.2004.11.092 
Dolistna aplikacja kwasu salicylowego wpływa korzystnie na parametry wzrostu i plonowania roślin Brassica campestris rosnących w glebie zanieczyszczonej ołowiem poprzez pozytywną regulację systemu obrony antyoksydacyjnej

\section{Streszczenie}

Toksyczność ołowiu $(\mathrm{Pb})$ wywiera silny wpływ na wzrost i produktywność roślin. Ochronna rola kwasu salicylowego (SA) jest dobrze znana w warunkach różnych stresów abiotycznych. Jednak niewiele wiadomo na temat indukowanego SA mechanizmu oporności na $\mathrm{Pb}$. W przeprowadzonych badaniach określiliśmy wpływ SA na rośliny gorczycy (Brassica campestris L.) w warunkach stresu wywołanego $\mathrm{Pb}$. Rośliny poddano działaniu trzech poziomów $\mathrm{Pb}$ wprowadzonych do gleby $(0,25,0,50,1,00 \mathrm{mM})$, z lub bez SA $(0,25 \mathrm{mM})$. Wzrost, wskaźniki plonowania oraz plon roślin uległy zmniejszeniu w zależności od nasilenia stresu indukowanego Pb. Egzogenna aplikacja SA wpłynęła na poprawę wzrostu i plonowania roślin. Wyniki analiz biochemicznych wykazały, że toksyczność $\mathrm{Pb}$ powodowała większe uszkodzenia oksydacyjne związane z obniżeniem zawartości nieenzymatycznych antyoksydantów, takich jak askorbinian i glutation, w obecności wyższych stężeń tego metalu. Aktywność enzymów antyoksydacyjnych (peroksydazy askorbinianowej APX, reduktazy monodehydroaskorbinianowej - MDHAR, reduktazy dehydroaskorbinianowej - DHAR, reduktazy glutationowej - GR, peroksydazy gwajakolowej - POD, S-transferazy glutationowej - GST i katalazy - CAT) była uzależniona od stężenia Pb. Zarówno nieenzymatyczne, jak i enzymatyczne elementy systemu obrony antyoksydacyjnej były pozytywnie regulowane po zastosowaniu SA, co powodowało mniejsze uszkodzenia oksydacyjne występujące w warunkach stresu Pb. Podsumowując, uzyskane wyniki sugerują, że egzogenna aplikacja SA łagodzi uszkodzenia oksydacyjne wywołane obecnością $\mathrm{Pb}$, a w konsekwencji prowadzi do lepszego wzrostu i plonowania gorczycy w warunkach ekspozycji na różne poziomy stresu indukowanego $\mathrm{Pb}$. 